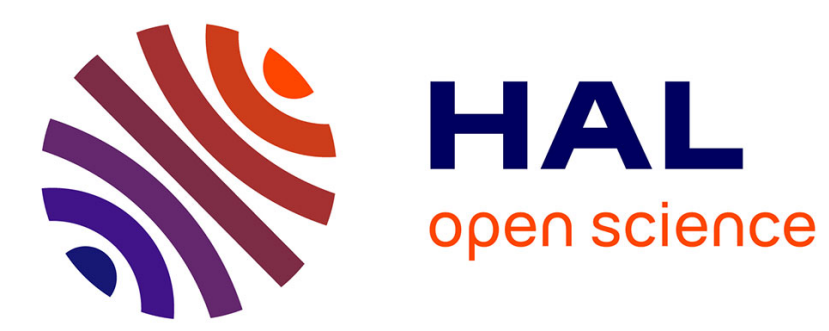

\title{
Framing the History of a Social Norm: A Response to Readers \\ Jean-Christian Vinel
}

\section{To cite this version:}

Jean-Christian Vinel. Framing the History of a Social Norm: A Response to Readers. 2016. hal01261899

\section{HAL Id: hal-01261899 \\ https://hal.science/hal-01261899}

Preprint submitted on 25 Jan 2016

HAL is a multi-disciplinary open access archive for the deposit and dissemination of scientific research documents, whether they are published or not. The documents may come from teaching and research institutions in France or abroad, or from public or private research centers.
L'archive ouverte pluridisciplinaire HAL, est destinée au dépôt et à la diffusion de documents scientifiques de niveau recherche, publiés ou non, émanant des établissements d'enseignement et de recherche français ou étrangers, des laboratoires publics ou privés. 
Framing the History of a Social Norm: A Response to Readers.

\section{Jean-Christian Vinel, Université Paris Diderot (Sorbonne Paris Cité)}

I'm quite grateful to the editors of Labor History for assembling such a prestigious symposium around The Employee: A Political History. The comments offered by the commentators are both insightful and challenging, and it is a particular pleasure for me to respond to them. Let me first offer some general remarks about the book and the story it tells, then move on to address some specific questions raised by the commentators: the history of foremen, the importance of gender and masculinity, the limits of industrial pluralism, and the road ahead for the history of American workers.

The thrust of The employee is to offer a social and political history of the term "employee" from the late 19th to the present times.. On one level, the book explains why the definition of "employee" under the NLRA has denied millions of semi professionals and white collar workers the right to organize. But to understand why American labor law recognizes the right of only some employed workers to act collectively to better their working conditions, I tried to trace the history of unionism as a social norm that sets the US apart from other democracies. Beyond the workers excluded from the collective bargaining process because they are misclassified as managers, the book reveals that "employee" holds a broader ideological importance --it conveys the conservative notion that efficient production requires from many workers who used judgment on the job a loyalty that is incompatible with unionism and collective bargaining.

As Erin Hatton and Sophia Lee have noted, The Employee thus operates a shift in the emphasis of labor history. While the "decentering" of labor history that Lee mentions in her comments is no doubt too strong a term (I see The Employee as an investigation expanding, rather than decentering the scope of labor history), in a way it does capture my effort to set the history of workers claiming the status of "employees" within the interpretive framework developed by policy historians. Indeed, I make a similar attempt to study the passing, adjudication, and implemention of legislation, and use history to reflect on problems that are likely to attend any future bout of legislative reform. While it is indubitably a history of workers and unions, The Employee is not a bottom up account of processes of self-determination. Rather, it includes a large cast of characters from businessmen to union leaders, Congressmen and Supreme Court justices, labor experts and workers to shed light on the contested, but largely invisible, battles that have taken place over the shaping of the sociological limits of "employee,." struggles which, for the most part, have too often remained below the radar of labor historians.

This leads me to an important caveat. Sophia Lee and Christopher Tomlins rightly note that the running thread of the book is legal history, and I'm glad (and somewhat relieved, since I am not a legal historian by training) that they see merit in my account of the rise and evolution of "employee" as a legal term. I refrained from calling it a "legal history", however, because while I don't see legal categories as a mere manifestation of class struggle, I do not believe that legal decisions are the driving force of history. The subtitle a "political history" is to suggest that law and society are interdependent and continuously inform one another through struggles and processes that are inherently political, are not foreordained, and involve many historical actors beyond judges. Most 
importantly, the book claims that historically, there is no mistaking the growing conservative imprint on the evolution of the category "employee." I tried to show the political and social dynamics (meaning anchored in society) of the conservative hegemony on this aspect of labor law.

It may be this mixture of policy and legal history that explains Howell Harris's troubles with the book. Harris's past work on foremen's unionism naturally led him to take a keen in interest in the two chapters that are devoted to that movement, and it was a pleasure for me to read that he found them -and so my account of the foremen's movement-- compelling. Harris, however, is critical of the preceding chapters, saying that they are "somewhat inadequate" as a preparation for the chapters on foremen. I beg to disagree, and would suggest that Harris does not understand my methodology. Like him, I appreciate the centrality of the foremen's struggle in the labor relation battles during World War II. Still, I had to go beyond the social dynamics of foremen's unions, or the logic of their corporate opponents because I needed to understand the legal, institutional, and political environment of this struggle. Without doing that, moving towards the "employment policy" that Lee and Hatton mention would not have been possible.

I thus needed to open the "black box" of the law to reconstruct the ideology, the social vision, and constitutional politics of labor reformers from the Progressive Era to the New Deal. Taken together the first three chapters make two important claims. First, they demonstrate that from the start, Progressive legislation operated without a clear social definition of the American working class, ie, without a clear sense of the relationship between employment and social subordination (unlike similar laws in countries like France). As a result, Progressive laws often fragmented working class people in groups of protected and unprotected employees. This was even the case with the Wagner Act. In spite of all the talk about economic security, economic citizenship and freedom of association in the 1930s, in fact New Dealers had no vision of citizenship and no constitutional strategy to offset the lack of a clear vision of workers as a social group. Second, these chapters show that the labor sociology developed by Commons and his students squarely placed the mass production foreman in the managerial realm, an alignment they deemed necessary for well ordained collective bargaining.

Foremen's unions challenged both trends. Not only did they force labor economists to rethink their labor sociology, but they moved the implementation of the Wagner Act toward a true civil right. Hence the main contention of the book -that foremen's unions expanded the democratic potential of the category "employee". Formed when engineers and other white collar groups were increasingly joining unions, the foremen's movement signaled that a broad sociological transmutation was now possible. No longer a mere trade off for manual work and the submission to the assembly line, the right to join a union would accrue to all wage and salaried workers as a broad social regulation of employment in mass production industries and beyond. Such a transformation of the common sense of unionism was the road not taken when the Taft-Hartley Act defined foremen (and by implication, other white collar people exercising autonomy, judgment or authority on the job) as part of the managerial realm. ${ }^{i}$

Thus the corporate litigators' victory in Taft-Hartley was one of cultural hegemony and ideology as much as sheer power in the workplace. But we must see that it was precisely this ideology of security that businessmen rejected, both the risk 
averseness that underlay it and its collective character. Along with control of the workplace, they fought foremen's unions to defend individualism, hard work, initiative symbolic values that had undergirded the rise of management to predominance.

While she is overall quite appreciative of my effort to historicize the category of "employee," Erin Hatton worries that my account may simply reify corporate discourse instead of analyzing it. She suggests that the analysis would be strengthened by exploring this history through the lens of gender and masculinity. Class and gender, she explains, are "inextricably bound together." In her comments Hatton does take note of my explanation for the relative absence of class and gender in the book, so let me simply emphasize that the book does not deny the centrality of race and gender for the understanding of the past and present of class politics in the US. Rather, my book seeks to supplement the wealth of work done on these questions by highlighting the historical emergence and evolution of yet another obstacle to workplace democracy.

Hatton, however, goes a bit further. What she asks, would have happened if the foremen had been predominantly African American? She ventures that corporate litigators successfully seized on the loyalty argument against foremen because theirs was struggle of white men against white men. The loyalty discourse, she suggests, may simply be a veil for what is in fact a pattern of exclusion based on whiteness and masculinity.

This is a more problematic proposal, for two reasons. First, it would have been difficult to explore business opposition to the foremen's unions though the lens of whiteness and masculinity because I found no hint of that in the sources. Second, like any historian, I'm reluctant to deal in explicitly counterfactual narratives. It would have taken such a different society for foremen to be predominantly African American in the 1940s that to wonder how corporate America would have responded to foremen's unions in such a context is a fruitless exercise. As many studies have shown, in spite of the CIO's efforts to promote racial equality, during WW2 the racial segmentation of the job market in the North was so strong that African American workers found it very difficult to simply open the door of factories involved in war production, and when they did, they were given lowly or dangerous jobs. While the creation of the FEPC in 1941 helped improve the ratio of Black workers, the agency lacked appropriate enforcement powers and racial tensions remained significant both in and out of the workplace. ii $^{\text {As }}$ for women, historians have shown that their presence in the factory was only accepted as a temporary necessity. Not until the 1960s and the adoption of Title VII was it possible to open the workplace. In this context, with the ranks of lower management being solidly white and male, how could the business battle against foremen's unions in the 1940s have been one of exclusion through whiteness or masculinity?

No doubt, the corporate litigators who opposed foremen's unions carried conceptions of whiteness and masculinity. But how decisive may these conceptions have been when compared to the political and ideological dynamics of their reaction against the Wagner Act --dynamics that scholars like Kim Philips Fein and Nelson Lichtenstein have analyzed? Indeed, much, of the recent work on postwar anti-unionism and neoliberalism demonstrates that conservatives take their free market ideas seriously regardless of race and genderiii. The well known anti-union lawyer Sylvester Petro, for example, did not need race or gender to make a sustained attack on the legitimacy of public sector unions, because he genuinely believed that collective bargaining and 
strikes by public employees posed a grave threat to the democratic ideal and developed a constitutional strategy to disempower them. .v $^{\text {iv }}$

Naturally, the corporate defense of the free market may well have led conservatives and advocates of neoliberalism to condone and to benefit from racial and gender divisions. Hatton's study of the rise of the temp industry is a prime example of the intersection of class and gender, and Bethany Moreton has demonstrated the extent to which Wal-Mart's rise was built on a gendered vision of the family (along with a service driven Christianity). Yet does it follow that historians of the corporate antiunion struggle should always frame their analysis in terms of race and gender? Indeed, we also need to see that from the 1980s onwards corporate victories for loyalty came at the same time as American businesses were increasingly embracing diversity management. $v$ As Nancy McLean explains, the National Association of Manufacturers and other business associations largely encouraged the Reagan administration's assault on labor law, but, they were much less enthusiastic when in 1985 the Justice Department set out to rescind EO 1146. ${ }^{\mathrm{vi}}$

Seeing the importance of the loyalty discourse to the neo-liberal push that has transformed the landscape of labor relations in the US and elsewhere is important if we are to gauge the extent to which the ageing of American labor law is as much as political defeat as a consequence of the emergence of the post-industrial society. This was not only a defeat of the American labor movement, which hewed to a male blue collar vision of the working class for much too long, it was also the defeat of the NLRB's industrial pluralists. From the 1940s onwards, these labor experts responded to the business quest for loyalty with a discourse of harmony through collective bargaining that they had inherited from the economic sociology pioneered by John R. Commons. This I argue, was the "other side of industrial pluralism" that we need to consider as we assess its influence over US labor relations.

Although he agrees that there was in fact another, more positive dimension to industrial pluralism than the literature traditionally recognizes, Christopher Tomlins disagrees with me on its historical meaning and importance. According to him, the business claim to employee loyalty is best seen as two interrelated, but different claims --one addresses the right to unionize to bargain over wages or salaries, while the other addresses the managerial control and direction of the work. While industrial pluralists denied the legitimacy of the first claim to loyalty, they acknowledged the legitimacy of the second, leaving an element of unfreedom at the heart of the employment relationship.

Tomlins is right, of course. Even if Industrial Pluralists had secured the recognition of the bargaining rights of the workers featured in this book, they would not have put workers on a path to true democratization of the workplace and selfmanagement. But as the Italian union leader and philosopher Bruno Trentin noted in his famous The City of Work: the Left and the Crisis of Fordism, the acceptance of the managerial direction and control of the work was the norm among leftist reformers generally (that is, throughout the western world). Few on the left challenged the managerial hierarchy that underwrote Fordism because they saw the regulation of the latter as a source of income redistribution and social justicevii. Wagner and Keyserling, the architects of the Wagner Act, never anticipated breaking with the fordist bargain; 
worker management was never a significant possibility in the US beyond the specific world of the skilled trades.

Yet, I would like to argue that the main problem in the US is that the control of the employer over the worker's conduct, even when it is established, does not trigger the same obligations as in Europe, where such control necessarily implies the "subordination" of employees, but also a degree of economic dependency. In the US today, many workers have the title of supervisor or manager but are in a situation of economic dependency that the law simply does not acknowledge. Instead, the law sanctions the employers' demand that that "managers" and "supervisors" prove their loyalty by actively fighting any incipient form of collective action by the workers they "supervise."

Where do we go from here? Sophia Lee and Erin Hatton outline two exciting strategies of research. The first is to move beyond the framework of the NLRA (Hatton mentions the Social Security Act and others) to study patterns of inclusion and exclusion. This is most important because it will not simply reveal the importance of specific discourses such as the business claim to loyalty, but it will also display important differences in how various laws define concepts such as "employee" and "supervisor". As Lee suggests, the Fair Labor Standards Act is a case in point. Not only is the definition of "supervisor" more inclusive under the FLSA, but the definition of "employee" is based on a criterion of "economic dependence" missing from the NLRA. Looking at the dynamics of the process whereby "employee" was given concrete meaning under social legislation crafted by reformers from the Progressive era onwards, we will get a fresh and important look at the New Deal order, which has rarely been studied from the inside.

Moreover, as Lee explains in her impressive comments, there is a broader employment history about which we do know too little because labor history in the 20th century has focused on unions and political economy. She suggests that a social history of all the statutes protecting employees would enhance our understanding of the way Americans - unionized or not-have experienced work. I fully agree, and would like to add that this work would enhance our understanding of the rise and fall of the New Deal order. While there is a broad consensus on the notion that the new deal resulted in expectations of security in the post-war era, the implementation of the policies that delivered this security has rarely been studied. An in depth study of the implementation of unemployment compensation, minimum wage, or medical leave would show us the New Deal in action, . If coupled with investigations at the local level, it would help us understand how such laws generated a feeling of security among workers. Depending on the sources, this would not simply tell us more about how federal regulation transformed the experience of work -what Lee emphasizes-- but also the extent to which it influenced workers' views of the Federal Government and its role.

There is another potential pay off in this history. As Lee explains, the definition of "employee" has recently been up for grabs well beyond the question of the appropriate line between workers and managers. In many ways, it is the distinction between "employees" and "independent contractors", as in the case of Fed Ex drivers, that now threatens the very security that labor law offers. ${ }^{\text {viii }}$

So far, this debate has largely focused on the notion that labor law categories are ill adapted to the organizational strategies that make what David Weil calls the "fissured 
workplace."ix The legal scholar Noah Zatz has argued however, that we should consider the "constructive power of law", that is the extent to which it was in fact possibilities offered by the law to employers that led them to devise an organization of work that is not simply more efficient and less costly, but also one that allows them to avoid unions. ${ }^{\mathrm{x}}$ Instead of seeing labor law and current legal categories like "employee" as an inadequate, antiquated response to the organization of work, we need to recognize how it helps create the very problem we are dealing with. According to Zatz, this means a return to a "structural" vision of the NLRA defining the mission of the NLRB as rectifying economic dependency by channeling all economic activity into forms conducive to collective bargaining.xi No doubt, the history of work that Sophia Lee calls for would contribute to this goal.

\section{REFERENCES:}

Carlson, Richard R. "Why the Law Still Can't Tell an Employee When It Sees One and How It Ought to Stop Trying”, 22 Berkeley J. Emp. \& Lab. L. 295 (2001).

Cowie, Jefferson, and Nick Salvatore. "The Long Exception: Rethinking the Place of the New Deal in American History," International Labor and Working Class History, 74 (2008) 1-32.

Davidov, Guy, Mark Freedland and Nicola Kontouris. "The Subject of Labour Law: 'Employees' and Other Workers," in Matthew Finkin and Guy Mundlak eds, Comparative Labor Law, Northampton: Edward Elgar Publishing, 2015, 115-132.

Durr, Kenneth. Behind the Backlash: White Working Class Politics in Baltimore, 1940-1980. Chapel Hill: The University of North Carolina Press, 2003.

Hatton, Erin. The Temp Economy: From Kelly Girls to Permatemps in Postwar America. Philadelphia: Temple UP, 2011.

Lichtenstein, Nelson. State of the Union. Princeton: Princeton UP, 2002.

McCartin, Joseph A. and Jean-Christian Vinel. "Compulsory Unionism: Sylvester Petro and the Career of an Anti-Union Idea", in The American Right and U.S. Labor: Politics, Ideology, and Imagination. Ed. Nelson Lichtenstein and Elizabeth Tandy Shermer, (Philadelphia: University of Pennsylvania Press, 2012): 226- 251

McLean, Nancy. Freedom is Not Enough: the Opening of the Workplace. Harvard: Russell Sage, 2006.

Moreton, Bethany. To Serve God and Wal-Mart. The Making of Christian Free Enterprise. Cambridge, MA: Harvard UP, 2009.

Norrell, Robert, "Caste in Steel: Jim Crow Careers in Birmingham, Alabama", Journal of American History, 73 (1986), 669-694.

Philips-Fein, Kim. Invisible Hands: The Businessmen's Crusade Against the New Deal. New York: Norton, 2009.

Shermer, Elizabeth T., "Counter-Organizing the Sunbelt: Right to Work Campaigns and AntiUnion Conservatism, 1943-1958”, Pacific Historical Review, vol. 78, n¹, 81-118. 
Trentin, Bruno, La Citta Del Travorro. Firenze: Firenze University Press, 2014.

Tomassetti, Julia, "The Legal Construction of Employment and the Re-institutionalization of U.S. Class Relations in the Postindustrial Economy”, PhD Dissertation, Sociology, UCLA, 2014.

Weil, David, The Fissured Workplace, Why work became so Bad For So Many and What Can Be Done to Improve It. Cambridge: Harvard UP, 2014.

Zatz, Noah D. "Beyond Misclassification: Tackling the Independent Contractor Problem Without Redefining Employment", ABA Journal of Labor \& Employment Law, vol. 26, no. 2 (2011).

Zieger, Robert. For Jobs and Freedom: Race and Labor in America Since 1965. Lexington:

The University Press of Kentucky, 2010.

\section{ENDNOTES}

${ }^{\text {i }}$ Still, I do believe that my account complements Harris's analysis in the Right to Manage, where he showed that beyond the profit motive, it was a quest for power and control of the workplace that fueled corporate opposition to foremen's unions. Companies were certainly not immune to using the flexibility in labor costs that unorganized supervisors offered, but this did not explain the sheer volume of their opposition to foremen's unions. As Harris explained, foremen's unionism was never a strong phenomenon, its seriousness "misjudged" by corporate America whose members were prey to largely exaggerated fears of lower management mutiny and worker-foremen alliances that would result in mob production. On the foremen as well as on other labor issues, Harris concluded, Businessmen simply overstated the threats that existed to their autonomy and power.

ii See inter alia, Durr, Behind the Backlash; Norell, "Caste in Steel”; Zieger, For Jobs and Freedom.

${ }^{\text {iii }}$ Recent work on the history of right to work states, shows that while race was central to the adoption of such laws in the South, it was not in the Southwest, where the likes of Goldwater sought first and foremost to keep unions at bay because they wanted to boost their economy, see Shermer, "Counter-Organizing the Sunbelt." .

${ }^{\text {iv }}$ See Joseph A. McCartin and Jean-Christian Vinel, "Compulsory Unionism: Sylvester Petro and the Career of an Anti-Union Idea."

${ }^{\mathrm{v}}$ Other scholars have argued that shorn of their original social democratic roots, claims to racial and gender equality are readily compatible with the individualism that neoliberalism promotes. See Cowie and Salvatore, "The Long Exception," 21.

${ }^{v i}$ Nancy McLean, Freedom is Not Enough.

vii Bruno Trentin, La Citta Del Travorro. To my knowledge there is no available translation in English.

viii An extended study of the implications of the Fed EX cases can be found in Julia Tomassetti, "The Legal Construction of Employment and the Re-institutionalization of U.S. Class Relations in the Postindustrial Economy."

${ }^{\text {ix }}$ David Weil, The Fissured Workplace.

${ }^{x}$ Noah D. Zatz, "Beyond Misclassification: Tackling the Independent Contractor Problem Without Redefining Employment." 
${ }^{\mathrm{xi}}$ As Zatz explains, this means going back to two Supreme Court decisions of the 1940s that defined "employee" based on a criterion of "economic dependence": United States. v. Silk 331 U.S. 704, and NLRB v. Hearst Publ'ns, Inc., 322 U.S. 111, (1944). Both were overturned by the Taft-Hartley Act in 1947. For a similar argument about the need to return to the Hearst decision, see Richard R. Carlson, "Why the Law Still Can't Tell an Employee When It Sees One and How It Ought to Stop Trying." 